\title{
INTER-RELATIONSHIPS OF CHIASMA FREQUENCIES IN NORMAL SET BIVALENTS IN PRESENCE OF EXTRA HETEROCHROMATIN AND EUCHROMATIN IN DACTYLIS GLOMERATA SUBSP. LUSITANICA
}

\author{
S. S. SHAH \\ Botany Division, I.A.R.I., New Delhi, India
}

Received 15.ii.65

\section{INTRODUCTION}

IN an earlier paper it was reported that in plants of Dactylis glomerata subsp. lusitanica having two supernumeraries, there was a positive correlation between chiasma frequencies of the normal set bivalents. Here, this relation is examined for plants with o, r, 3 and 4 supernumeraries and a trisomic plant. Similar studies have been carried out in Zea mays trisomic for a member of the standard complement (Mather, I939). In this species the effect of such an addition was to increase the upper limit of chiasma formation for the complement and reduce competition.

\section{MATERIAL AND METHODS}

With the exception of plants 7 and 8 , all other plants with one $B$ and all those with 4 B's were obtained from the cross, Plant I (o supernumerary) $\times$ Plant 9 (3 supernumeraries) and the reciprocal cross (see table I). All the plants with two supernumeraries, the data from which were presented earlier (Shah, 1964), originated from the same cross. Hence all these plants are sibs. The asynaptic plant originated from a $4 x \times 2 x$ cross and was a polyhaploid. This plant had two supernumeraries. The trisomic originated from the cross involving this asynaptic plant.

Dactylis glomerata subsp. lusitanica has a standard complement of seven pairs of chromosomes. The supernumeraries pair among themselves when more than one is present in the same cell and hence are homologous. Acetocarmine smears were used for scoring and data were obtained for both diakinesis and metaphase. In the absence of differential terminalisation, scoring at these stages as compared to diplotene has no disadvantage in such studies. When terminalisation is complete, such a differential terminalisation is considered unlikely by Mather (1936).

The appropriate method of partitioning variances is one of "incomplete classification", since the seven bivalents could not be distinguished from each other. The total variance is partitioned into two components, inter-nuclear and intra-nuclear components. A higher inter-nuclear component indicates a positive correlation while a higher intra-nuclear component indicates a negative correlation. Negative correlation suggests "competition" for chiasma formation between bivalents (Mather, 1936). Details about the method of partitioning the inter- and intra-nuclear variances are given in Mather (1936). For testing the homogeneity of variances Bartlet's test was used.

Details concerning the time of growing the material and the technique of fixation are given in Shah ( 1963 ).

\section{RESULTS}

In the case of the two plants with no supernumeraries, both the intraand inter-nuclear variance components are heterogenous $(\mathrm{P}<0.01)$. Hence comparing the intra- and inter-nuclear variances for the group as such has certain difficulties. A similar situation was found with respect to the plants with two supernumeraries also (Shah, 1964). Here the method suggested by Cochran and Cox (1962, p. 554) for pooling the data from a series of latin square experiments with heterogeneity of error component 
was followed. They observe that if the error is heterogenous, in the case of tests involving pooling such variances, the $F$ value obtained is an overestimate, i.e. too many significant results are obtained. The tabular F value corresponding to the degrees of freedom of the experiment which has

TABLE !

Variance components for plants with $0,1,3$ and 4 supernumeraries

\begin{tabular}{|c|c|c|c|c|c|}
\hline \multirow{2}{*}{$\begin{array}{c}\text { No. of } \\
\text { super- } \\
\text { numeraries }\end{array}$} & \multirow{2}{*}{$\begin{array}{c}\text { Plant } \\
\text { no. }\end{array}$} & \multirow{2}{*}{$\begin{array}{l}\text { No. of } \\
\text { cells }\end{array}$} & \multicolumn{2}{|c|}{ Variance components } & \multirow{2}{*}{$P$ values } \\
\hline & & & $\begin{array}{l}\text { Intra- } \\
\text { nuclear }\end{array}$ & $\begin{array}{l}\text { Inter- } \\
\text { nuclear }\end{array}$ & \\
\hline 0 & $\begin{array}{c}1 \\
\text { sample 1 } \\
\text { sample } 2 \\
2 \\
\text { sample 1 } \\
\text { sample 2 } \\
\text { Pooled es }\end{array}$ & $\begin{array}{r}86 \\
100 \\
47 \\
46 \\
56 \\
\text { imate }\end{array}$ & $\begin{array}{l}0.2359 \\
0.2728 \\
0.0770 \\
0.1097 \\
0.1984\end{array}$ & $\begin{array}{l}0.1904 \\
0.2073 \\
0.0737 \\
0.0956 \\
0.1591\end{array}$ & $\begin{array}{c}0.20>P>0.10 \\
0.05>P>0.01 \\
>0.25 \\
>0.20 \\
0.1>P>0.05 \\
\left(V_{1}=600 ; V_{2}=99\right)\end{array}$ \\
\hline 1 & $\begin{array}{c}3 \\
\text { sample } 1 \\
\text { sample } 2 \\
4 \\
5 \\
6 \\
7 \\
8 \\
\text { Pooled es }\end{array}$ & $\begin{array}{r}50 \\
50 \\
49 \\
50 \\
41 \\
50 \\
70 \\
\text { imate }\end{array}$ & $\begin{array}{l}0.1019 \\
0.1505 \\
0.1050 \\
0.0762 \\
0.1638 \\
0.1895 \\
0.2891 \\
0.1611\end{array}$ & $\begin{array}{l}0.0833 \\
0.1206 \\
0.0700 \\
0.0829 \\
0.2360 \\
0.2139 \\
0.2472 \\
0.154^{1}\end{array}$ & $\begin{aligned} 0.20 & >\mathrm{P}>0.10 \\
0.20 & >\mathrm{P}>0.10 \\
0.05 & >\mathrm{P}>0.01 \\
& >0.25 \\
0.1 & >\mathrm{P}>0.05 \\
& >0.20 \\
& >0.20 \\
& >0.25 \\
\left(V_{1}=\right. & \left.420 ; V_{2}=69\right)\end{aligned}$ \\
\hline 3 & $\begin{array}{c}9 \\
\text { sample I } \\
\text { sample } 2 \\
\text { sample } 3 \\
\text { Pooled es }\end{array}$ & $\begin{array}{r}79 \\
18 \\
190 \\
\text { rimate }\end{array}$ & $\begin{array}{l}0.1857 \\
0.2090 \\
0.1704 \\
0.1770\end{array}$ & $\begin{array}{l}0.1723 \\
0.2094 \\
0.1337 \\
0.1488\end{array}$ & $\begin{array}{c}>0.25 \\
>0.25 \\
0.05>\mathrm{P}>0.01 \\
0.05>\mathrm{P}>0.01 \\
\left(\mathrm{~V}_{1}=1722 ; \mathrm{V}_{2}=284\right)\end{array}$ \\
\hline 4 & $\begin{array}{c}10 \\
11 \\
\text { sample I } \\
\text { sample } 2 \\
\text { Pooled es }\end{array}$ & $\begin{array}{r}56 \\
\\
52 \\
17 \\
\text { imate }\end{array}$ & $\begin{array}{l}0.2347 \\
0.2601 \\
0.2157 \\
0.2427\end{array}$ & $\begin{array}{l}0.2467 \\
0.2473 \\
0.2188 \\
0.2433\end{array}$ & $\begin{array}{c}>0.25 \\
>0.25 \\
>0.25 \\
>0.25 \\
\left(V_{1}=122 ; V_{8}=750\right)\end{array}$ \\
\hline
\end{tabular}

the highest error variance, gives the upper limit of the true $F$ value. In case of values beyond these limits, i.e. $F$ values lower than one corresponding to the combined degrees of freedom and the values higher than the $F$ values corresponding to the degrees of freedom for the experiment having the highest error variance, there is no difficulty in deciding whether the $\mathbf{F}$ value is significant or not. In case of values lying within this range no clear decision of this nature could be made (for details see Cochran and Cox, 1962, p. 554). This is used as a basis of comparison in the present studies also, although the experimental set-up is of a hierarchal nature here. The pooled estimates with respect to the intra- and inter-nuclear variances for the two plants with no supernumeraries are given in table $\mathrm{I}$. The intranuclear component is higher. However, using the degrees of freedom with 
respect to plant $\mathrm{I}$, sample 2 , which has the highest inter-nuclear variance, the $\mathrm{F}$ value is not significant $(0.1>P>0.05)$. If the combined degrees of freedom for all the four samples is used for the pooled estimates, the $F$ value is highly significant $(\mathrm{P}>\mathrm{O} \cdot \mathrm{OI})$. Hence in such a case a clear decision for this group could not be made, however the data suggest the presence of a higher intra-nuclear variance, i.e. a negative correlation, since with respect to the combined degrees of freedom the $P$ value is less than $0 \cdot 01$.

In plants with one supernumerary, both the intra- and inter-nuclear variances for the 6 plants are heterogeneous $(\mathrm{P}<0.01)$. With respect to the pooled estimates for the plants with one supernumerary, the intranuclear component is slightly higher. Even when the combined degrees of freedom for all the six plants are used, the intra-nuclear variance is not significantly higher. In the plant with three supernumeraries, both the intra- and inter-nuclear variances for the three samples are homogeneous $(0.25>\mathrm{P}>0.1)$. With respect to the pooled estimates, the intra-nuclear variance is significantly higher $(0.05>\mathrm{P}>0.01)$. Both the variance components are homogeneous for the plants with 4 supernumeraries $(\mathrm{P}>0.25)$. In the case of pooled estimates for this group, the inter-nuclear component is slightly higher but not significantly so $(P>0.25)$.

In the trisomic plant the three homologous chromosomes formed a trivalent in nearly half of the PMCs. In this plant both the variance components for the two samples are homogeneous $(P>0.50)$. With respect to the pooled estimates the inter-nuclear component is slightly higher, but not significantly so $(P>0 \cdot 20)$. In the asynaptic plant, both the intra- and inter-nuclear variances are heterogeneous $(\mathrm{P}<0 \cdot 0 \mathrm{I})$. With respect to the pooled estimates, even when the combined degrees of freedom are used $\left(V_{1}=203 ; V_{2}=1242\right)$, the differences are not significant.

\section{DISCUSSION}

Most of the plants used here are sibs and are genetically more alike than plants from open-pollination. In such material the effect of the dosage of supernumeraries is less confounded with genotype differences than in plants obtained from an open-pollinated population. This will be all the more so in a cross-pollinated plant like Dactylis glomerata subsp. lusitanica.

The most important aspects of the results are that in plants with no supernumeraries there is an indication of a negative correlation, while in the plant with three supernumeraries there is a significant negative correlation. In the group of plants with I and 4 supernumeraries, there is no indication of a correlation. In earlier studies, plants with 2 supernumeràries, which are sibs to most of the plants described here, showed a significant positive correlation (Shah, 1964). These supernumeraries are homologous, still there does not seem to be a linear change in correlation with change in their number. A non-linear effect of the heterochromatin has also been reported for the effect of $\mathrm{Y}$ chromosome dosage on male fertility in Drosophila (Hannah, 195I). Some of the deficient Y's and a complete loss of a $\mathrm{Y}$ chromosome cause sterility in Drosophila males. However XYYY males are also sterile, and there is some evidence that the XYYYY condition may be lethal.

No statistical analysis has been carried out for the differences with respect to the mean chiasma frequency for the five groups. However, 
these do not seem to have been appreciably affected. The mean chiasma frequencies for all the plants belonging to the above mentioned five groups except for plant No. 8 lie within the range of variation of the two plants without supernumeraries.

More data from similar studies with other species will be needed to generalise about the effect of heterochromatin on chiasma formation in euchromatin.

In the trisomic plant the two variance components are of more or less the same magnitude, while in diploid plants without any supernumeraries, there is an indication of a negative correlation. A reduction in the extent of negative correlation was found in maize trisomics by Mather (1939).

TABLE 2

Variance component for trisomic and asynaptic plant

\begin{tabular}{|c|c|c|c|c|c|}
\hline \multirow{2}{*}{$\begin{array}{l}\text { Chromosome } \\
\text { number of } \\
\text { plant }\end{array}$} & \multirow{2}{*}{$\begin{array}{c}\text { Sample } \\
\text { no. }\end{array}$} & \multirow{2}{*}{$\begin{array}{l}\text { No. of } \\
\text { cells }\end{array}$} & \multicolumn{2}{|c|}{ Variance components } & \multirow{2}{*}{$P$ value } \\
\hline & & & $\begin{array}{l}\text { Intra- } \\
\text { nuclear }\end{array}$ & $\begin{array}{c}\text { Inter- } \\
\text { nuclear }\end{array}$ & \\
\hline $\begin{array}{c}2 n+1 \\
\text { (trisomic) }\end{array}$ & $\stackrel{2}{2}$ Pooled & $\begin{array}{c}5^{0} \\
5^{1} \\
\text { timate }\end{array}$ & $\begin{array}{l}0.2438 \\
0.2510 \\
0.2475\end{array}$ & $\begin{array}{l}0.2598 \\
0 \cdot 2800 \\
0 \cdot 2700\end{array}$ & $\begin{array}{c}>0.25 \\
>0.25 \\
>0.20 \\
\left(V_{1}=99 ; \quad V_{2}=606\right)\end{array}$ \\
\hline $\begin{array}{c}2 n+2 s \\
\text { (asynaptic } \\
\text { plant) }\end{array}$ & $\begin{array}{c}\text { I959 } \\
\text { sample I } \\
\text { sample } 2 \\
\text { I960 } \\
\text { sample I } \\
\text { sample } 2 \\
\text { Pooled }\end{array}$ & $\begin{array}{r}41 \\
49 \\
67 \\
50 \\
\text { timate }\end{array}$ & $\begin{array}{l}0.4727 \\
0.4577 \\
0.2814 \\
0.3600 \\
0.3^{800}\end{array}$ & $\begin{array}{l}0.6573 \\
0.4871 \\
0.3191 \\
0.2641 \\
0.4122\end{array}$ & $\begin{array}{c}0.1>P>0.05 \\
>0.25 \\
>0.20 \\
0.1>P>0.05 \\
>0.25 \\
\left(V_{1}=40 ; V_{2}=246\right)\end{array}$ \\
\hline
\end{tabular}

The chiasma frequency in the trisomic studied in the present investigation was 12.24 per cell at diakinesis, while at metaphase the corresponding figure was $1 x \cdot 80$. These figures are not higher than those found in the diploid lusitanica plants. Mather (1939) observed an increase in the number of chiasmata formed in maize trisomics. In the present case, the asynaptic parent might have reduced the chiasma frequency in the trisomic.

In the case of the asynaptic plant, there was a considerable increase in the total variance. However, the two variance components do not differ significantly (table 2). The asynaptic plant had two supernumeraries. Plants with two supernumeraries showed a positive correlation of chiasma frequency with respect to the chromosomes of the normal set (Shah, 1964). The effect of asynapsis here could not be easily assessed since the parents of the normal plants with two supernumeraries and the asynaptic plant are different. An increase in total variance could be associated with a disproportionate increase in one of the components, e.g. if, in the cell where asynapsis of some of the potential bivalents takes place, there is a compensatory increase of chiasma frequency in other bivalents then there will be a disproportionate increase of the intra-cellular component. Other asynaptic situations would furnish interesting information if examined from this viewpoint. 


\title{
5. SUMMARY
}

I. In Dactylis glomerata subsp. lucitanica, the effect of extra heterochromatin on the inter-relationships of chiasma frequency in the normal complement was studied. In the diploids with no extra heterochromatin there was a negative correlation in the normal set. In a plant with 3 extra heterochromatic supernumeraries there was also a significant negative correlation, while in the group of plants with two supernumeraries there was a significant positive correlation. In plants with I and 4 supernumeraries there was no correlation. This seems to be one more role which heterochromatin plays in cellular processes.

2. In the trisomic plant, there was no correlation of chiasma frequencies, and there was no increase in the upper limit of chiasma formation. Data are compared with the earlier work on maize trisomics.

3. In the asynaptic plant, the total variance increased considerably. However, the variance components are not significantly different.

Acknowledgments.-I am thankful to Dr G. L. Stebbins, Dr B. P. Pal and Dr M. S. Swaminathan for providing facilities to carry out this work. I am also thankful to Dr P. N. Saxena, Dr M. S. Swaminathan and Dr H. K. Jain for reading the manuscript and for suggestions.

\section{REFERENCES}

Cochran, w. G., AND cox, G. M. 1962. Experimental Designs. 2nd edition. Asia Publishing House.

hanNaH, A. 1951. Localisation and function of heterochromatin in Drosophila melanogaster. Adv. Genet., 4, 87-125.

MATHER, K. 1936. Competition between bivalents during chiasma formation. Proc. Roy. Soc. Lond., B, I20, 208-227.

MATHER, X. 1939. Competition for chiasmata in diploid and trisomic maize. Chromosoma, $I$, I19-129.

SHAH, s. s. 1963. Studies on supernumerary chromosomes in the genus Dactylis. Chromosoma, 14, 162-185.

sHAH, s. s. 1964. Inter-relationships of chiasma frequency in bivalents in Dactylis glomerata subsp. lusitanica. Heredity, 19, 736-738.

\section{EFFECTS OF INBREEDING AND BRISTLE NUMBER ON REPRO- DUCTIVE SUCCESS IN SELECTED LINES OF DROSOPHILA MELANOGASTER}

\author{
G. MCBRIDE \\ Department of Animal Husbandry, University of Queensland, \\ Brisbane, Australia \\ and \\ J. W. J'AMES \\ School of Wool Technology, The University of New South Wales, \\ Kensington, Australio \\ Received 5.ii.65
}

\section{INTRODUCTION}

WHEN populations of plants or animals are selected for a metric trait, a number of changes usually occur: in particular, the mean of the metric trait is altered, the coefficient of inbreeding rises (Robertson, I96I) and 